\title{
ITEM out of WG 3.7 \\ Is there any life out there?
}

\author{
Javier Osorio, Jacques Bulchand and Jorge Rodriguez \\ Las Palmas de Gran Canaria University, Spain
}

\begin{abstract}
At the IFIP WG 3.7's Working Conference two years ago, we presented a paper offering a classification of the Group's published works by research topics and methodologies. The scope was exclusively internal and some conclusions about the output and future challenges were suggested. We now focus our attention externally, exploring the overall activity in the field of information technology for educational management. On the one hand, we have concentrated on practical works, mainly represented by computer applications for commercial purposes and, on the other hand, we have analysed high level theoretical works. After our review process, we became aware of the preponderance of practical activity in the field, with little support from the theoretical perspective. However, we have found a similar orientation when comparing the research topics and methodologies applied by authors in research journals with those adopted by authors who have contributed to WG 3.7.
\end{abstract}

Keywords: Information technology for educational management, research activity, research methodologies, practical work, computer applications for educational management.

\section{INTRODUCTION}

We have been able to find numerous references to the application of information technology (IT) in the business area dating from the first appearance of computers (McKinsey \& Company, 1968; Wagner, 1970; Gorry and Scott Morton, 1971; Lubas, 1976). In effect, the first advances in computing, which basically focused on providing tools to support arithmetical calculation, were quickly followed by the development of informatic applications for business management. The high performance achieved in data processing, especially in areas of an eminently quantitative nature, such as accounting and payroll management, justified the high investments that large corporations made in IT (Corr, 1977; Clancy, 1978). Later, and encouraged by the apparent success achieved in private business management, other sectors also opted to invest in IT. One of the sectors that

Please use the following format when citing this chapter:

Osorio, J., Bulchand, J. and Rodriguez, J., 2009, in IFIP International Federation for Information Processing, Volume 292; Evolution of Information Technology in Educational Management; Eds. Tatnall, A., Visscher, A., Finegan, A., O’Mahony, C., (Boston: Springer), pp. 31-42. 
joined the informatic wave was that of education, whose management needs were similar to those of business management, especially in the case of large institutions such as universities, ministries and education departments. Thus, accounting and payroll management similarly benefited from the implementation of IT within education organisations.

The use of computers in the education area really took off in the 1980s with the appearance of personal computers and later, in the early 1990s, with the growing popularity of an already mature tool, the Internet (Linn, 1998; Miesing, 1998). Focusing now on applications in the educational field, we have witnessed various phases in which most software production shifted from applications for education management to applications to support teaching and learning (William, 2002). The available power of computers at the time initially favoured the development of basic administration applications and, as that power increased, so did the development of highly complex applications where alphanumeric, graphic, sound and visual information combined to permit the development of effective applications for teaching and learning (Spencer, 1991).

One problem that has arisen in the education area is the efficient use of IT resources to optimise education management. In that respect, the lack of theories and know-how regarding how to plan or integrate IT for education management led to the appearance of numerous problems. The growth in investments by education authorities, particularly in the most developed countries, justified the initiation of studies of the problem in order to find empirically validated solutions. Thus, the specialist journals and forums began to address the problem of IT in education management in a different way. The increasing number of seminal works on the topic appeared alongside the growing presence of computers in the field of education (Heinich, 1970; Fleming and Levie, 1978). It should be stressed that this process did not take place in isolation; it benefited from the advances and contributions of the information systems (IS) area, which, to a great extent, fuels the area of study that concerns us. In that context, 1995 saw the creation of a working group within the Technical Committee for Education of the IFIP ${ }^{2}$, under the auspices of UNESCO, that focused exclusively on the area of information technology for educational management, from which its acronym (ITEM) ${ }^{3}$ is taken. However, the existence of this workgroup by no means meant that its members monopolised this line of research; there are numerous contributions from different areas that have helped enrich this discipline.

This work aims to contextualise the work of that working group in relation to the activity undertaken in other areas, and especially in the research published in journals listed in the Science Citation Index (SCI) of the Institute for Scientific Information (ISI).

IFIP: International Federation for Information Processing

The working group in question is identified by the initials WG 3.7 of IFIP TC-3 (www.ifip.org) 


\section{CONTEXTUALISATION}

To conduct the proposed study, we performed an operation to find and identify works in the field of ITEM. At the same time, we moved away from the purely academic and research environment to explore the commercial context in an attempt to somehow link the reality of the use of ITEM with that reflected in the relevant research. To that end, we used several sources. One source was an Internet search for commercial software used for educational management. Another was a similar search for research and diffusion groups in this field and the third was a search of the ISI data base for articles related to the topic. In order to establish criteria of comparison, our reference was the work by Osorio and Bulchand (2007), which focused on studying the activity of working group WG 3.7 during its first ten years.

In general, we based the search for information on the descriptors of the field of study that concerns us, namely "information technology for educational management". Since the relevant publications often use synonyms, such as "computer" instead of information technology and "school administration" to refer to educational management, we also used those words in the searches by means of Boolean combinations. First of all, we conducted a generic search using the Google Scholar search engine in order to know, in general terms, the extent of academic production in this topic. We repeated that search using generic Google and the same search parameters. The aim was to identify whether we could find indicators of the production of relevant content outside the purely academic field that was appreciably different from those found using Google Scholar. The next step was to explore the offer of applications and software for educational management that is available on Internet. Thus, we considered the possibility of estimating the fundamentally commercial production and finding a dichotomy between the academic and the commercial components. Finally, we accessed the ISI data base and searched for similar terms in journals of academic excellence. In this case, the search focused on journals in the specific field of "education" within the area of social sciences.

\section{RESULTS}

\subsection{General and Academic}

One of the problems associated with an Internet search for information is the difficulty of filtering the resulting information so that the results match the established criteria. In effect, the search for the words represented by the acronym ITEM resulted in millions of documents that contained some of the four words but relatively few that specifically included the whole term. The problem becomes more complicated because documents that are not directly related to the term appear first since they have higher hit rate on Internet. However, when the search was refined, most of the results corresponded to 
academic documents and books mostly written by authors from the university environment, with few documents written by authors from the business field.

When we confined our search to the academic field and used a search engine like Google Scholar, after refining several times ${ }^{4}$, we found a total of 35 references that complied fully with the criteria of the area that concerned us. The predominance of books published by WG 3.7 stood out as a result of its biannual meetings. This led us to conclude that, in the academic sector, that group constitutes a referent with outstanding production. However, the above does not preclude the presence of numerous authors who have undertaken work in this field and whose collaboration with the works of WG 3.7 could be very enriching.

\subsection{Software}

The search for specialist commercial software for educational management in primary, secondary and university education centres constituted a conclusive factor that supported the basically applied and practical nature of the field of ITEM. The high number of informatic applications available commercially on Internet reflects the importance of this activity and goes some way to explain the scarcity of works from the high level academic sphere, as we shall see later. Using a single search engine and taking the English language as the reference, we identified 155 commercial software packages. That number can be considered quite high and reflects, on the one hand, the commercial interest in this field and, on the other, the absence of a clear topselling application in the sector, at least in the Anglo-Saxon context.

The applications for educational administration or management that we found cover uses for timetable management and classroom allocation, marks management, tracking student evolution as well as for accounting and financial management in education centres, although that last category displayed the lowest presence in the overall results. We should point out that the results of this search basically showed commercial applications and that there are numerous tools developed in-house by many education centres that, although operational, are not reflected in the search results.

In short, there is a strong imbalance between the practical dimension of ITEM, with its strong contribution in terms of investment effort and manhours, and the more theoretical dimension, focused on publications that determine the achievement of better results in the application of informatic tools in the field of educational management. That situation is not repeated in the area of the use of information technology in the business world, where a great number of informatic applications are available, some of which can be considered sales-leaders in the sector. There is also a broad base of

4 By way of example, a search using the terms "computer* education* management" obtained 2,442 references although most of them could not be classified as belonging to our field of study. 
publications and references to strategies and recommendations to promote best practices in their application in business management.

There is a strong link between the ITEM field and the more generic field of information systems and information technology (IS/IT). Some answers to the problem related to the introduction of IT in educational management may be sought in the latter field, since its larger base of knowledge offers solutions that, in the main, can adapt to the area that concerns us by maintaining nuances that are unique in the discipline of educational management.

\subsection{Journals indexed in the ISI}

With regard to the results of the ISI data base search, the most notable is the date of the first publication on the topic, which was in 1967. This demonstrates the early interest in the field, well before personal computers became known. Another notable characteristic of this group of publications is the low number of published articles that can be considered wholly related with our area of study compared with the numerous publications within the education area. However, even more noticeable is the high number of publications within that area but outside what could be called the "high academic level". This situation may be due to the fact that the field of study has an eminently practical nature with little margin for a particular theoretical body to be established. In addition to the above, this field has reached maturity and it hardly seems necessary to produce new theoretical constructs except in the case of new paradigms or theories appearing in the fields of management or information systems, on which, to a great extent, our field of study draws. Moreover, it should be said that the most dynamic agent of change in this discipline is information technology, which is in a state of constant evolution and whose advances have more impact from a practical than a scientific perspective. Another factor that might explain the scarcity of high level publications is the fact that the low impact of these publications for the scientific community generates little personal and professional motivation. One of the most representative indicators of that low impact is the small number of times that an article has been cited. This is demonstrated by the fact that, of the 48 articles that can be considered to belong to this discipline, $31(64.6 \%)$ have never been cited in another publication indexed in the ISI, against the 17 that have been cited, the most cited having been cited 8 times.

In order to compare the topics that were considered in the research on the ISI data base and that can be considered characteristic of ITEM with those undertaken within WG 3.7, that group's articles were classified into the following areas: (a) Strategies to integrate IT into educational management; (b) Assimilation and integration of IT into educational management; (c) ITEM state of the art: The discipline's present situation and trends; (d) Assessment of IT support to educational management; (e) National, regional and local experience in the use of IT for educational management; (f) IT 
applications in educational management; and (g) Teacher and manager training in the use of IT for educational management. Table 1 displays the data in absolute and relative terms of both samples.

Table 1: Papers classified by research subject

\begin{tabular}{|c|c|c|}
\hline Topic & $\begin{array}{l}\text { ISI Web } \\
\text { of Science } \\
1968-2007 \text { ) } \\
\text { N. } \\
\%\end{array}$ & $\begin{array}{l}\text { IFIP } \\
\text { WG 3.7 } \\
\text { (1995-2005) } \\
\text { N. } \\
\% \\
\end{array}$ \\
\hline Strategies to integrate IT into educational management. & $\begin{array}{l}6 \\
12.5 \% \\
\end{array}$ & $\begin{array}{l}9 \\
8.7 \%\end{array}$ \\
\hline $\begin{array}{l}\text { Assimilation and integration of IT into educational } \\
\text { management. }\end{array}$ & $\begin{array}{l}9 \\
18.8 \%\end{array}$ & $\begin{array}{l}27 \\
26.2 \%\end{array}$ \\
\hline $\begin{array}{l}\text { ITEM state of the art: The discipline's present situation } \\
\text { and trends. }\end{array}$ & $\begin{array}{l}9 \\
18.8 \% \\
\end{array}$ & $\begin{array}{l}3 \\
2.9 \% \\
\end{array}$ \\
\hline Assessment of IT support to educational management. & $\begin{array}{l}6 \\
12.5 \% \\
\end{array}$ & $\begin{array}{l}20 \\
19.4 \% \\
\end{array}$ \\
\hline $\begin{array}{l}\text { National, regional and local experience in the use of IT } \\
\text { for educational management. }\end{array}$ & $\begin{array}{l}6 \\
12.5 \%\end{array}$ & $\begin{array}{l}18 \\
17.5 \%\end{array}$ \\
\hline IT applications in educational management. & $\begin{array}{l}10 \\
20.8 \%\end{array}$ & $\begin{array}{l}20 \\
19.4 \%\end{array}$ \\
\hline $\begin{array}{l}\text { Teacher and manager training in the use of IT for } \\
\text { educational management. }\end{array}$ & $\begin{array}{l}2 \\
4.1 \% \\
\end{array}$ & 6 \\
\hline TOTAL & $\begin{array}{ll}48 \\
100 \%\end{array}$ & $\begin{array}{l}103 \\
100 \%\end{array}$ \\
\hline
\end{tabular}

The following conclusions can be drawn from Table 1: the figures regarding the relative participation of the papers classified in the various research subjects show values in similar ranges for several of the identified categories. In some categories, the two figures are very close, as in the case of IT applications in educational management, where the difference is only $1.4 \%$. It is this category that appears most frequently in the publications in the SCI of the ISI, with the peculiarity that it was quite a common topic in the 1970s and early 1980s. Hardly any papers that can be included in this category have appeared more recently. The reason for that chronological distribution may be that, during the mentioned period, information technology applications in educational management constituted a novelty and, since it was an innovative field, emphasis focused on of the announcement of new tools.

However, the greatest difference between the two groups of publications can be found in the group ITEM state of the art: The discipline's present situation and trends, in which the high presence of articles from the ISI data base, in percentage terms, contrasts with the almost token presence of WG 3.7 publications. The reason for that significant difference may lie in the editorial philosophy of the many journals that usually favoured the publication of articles of an integrative nature that addressed the developments and paradigms characteristic of a determined area of knowledge. This was because such articles were of great interest both to experienced and to new scholars in the discipline who wished to know the views of other, more 
erudite, academics on the general situation of the discipline. Moreover, novice readers were also able to extract from a single article a compendium of knowledge that they would otherwise have had to read different articles to obtain.

Furthermore, focusing on research methodologies and making use of their classification into the following types: (a) Theoretical - conceptual; (b) Theoretical - illustrative; (c) Empirical - case studies; and (d) Empirical field studies, we compared them with the methodologies applied in WG 3.7 publications, as shown in Table 2, and reached the following conclusions. Firstly, there is a strong similarity between the percentages of theoretical and empirical articles in the two categories, the difference being only $2.8 \%$ in both cases. Secondly, although in the case of empirical research, the proportions in the two groups are very similar, there is the paradox that the tendency between the two groups is inverse. In other words, the proportion of articles based on case studies in one group is very similar to that of articles based on field studies in the other, and vice versa, with articles using field studies as the methodology predominant in the articles from the SCI of ISI. One possible explanation for the above may lie in the tendency of publications indexed in the SCI to publish articles based on this methodology because it was considered "more scientific" due to the more universal conclusions that are usually associated with it.

Table 2: Papers classified by research methodology

\begin{tabular}{|c|c|c|}
\hline Research methodology & $\begin{array}{l}\text { ISI Web } \\
\text { of Science } \\
\text { (1968-2007) } \\
\text { N. } \\
\%\end{array}$ & $\begin{array}{l}\text { IFIP } \\
\text { WG 3.7 } \\
(1995-2005) \\
\text { N. } \\
\% \\
\end{array}$ \\
\hline Theoretical studies & $\begin{array}{l}21 \\
43.8 \%\end{array}$ & $\begin{array}{l}48 \\
46.6 \%\end{array}$ \\
\hline Theoretical - conceptual & $\begin{array}{l}9 \\
18.8 \%\end{array}$ & $\begin{array}{l}18 \\
17.5 \%\end{array}$ \\
\hline Theoretical - illustrative & $\begin{array}{l}12 \\
25 \%\end{array}$ & $\begin{array}{l}30 \\
29.1 \%\end{array}$ \\
\hline Empirical studies & $\begin{array}{l}27 \\
56.2 \%\end{array}$ & $\begin{array}{l}55 \\
53.4 \%\end{array}$ \\
\hline Empirical - case studies & $\begin{array}{l}8 \\
16.6 \%\end{array}$ & $\begin{array}{l}37 \\
35.9 \%\end{array}$ \\
\hline Empirical - field studies & $\begin{array}{l}19 \\
39.6 \%\end{array}$ & $\begin{array}{l}18 \\
17.5 \%\end{array}$ \\
\hline TOTAL & $\begin{array}{l}48 \\
100 \%\end{array}$ & $\begin{array}{l}103 \\
100 \%\end{array}$ \\
\hline
\end{tabular}

\section{CONCLUSIONS}

ITEM is a field that is strongly influenced by innovations in IT, as demonstrated by the content of a great number of publications that can be classified as belonging to this category. This contingent character regarding 
technology has aroused greater interest in the area related to the marketing of informatic products than at a scientific-academic level, and as the scientific level of the publications increases, that interest appears to obey an inversely proportional relationship to that level.

The community researching this topic could find a meeting point in WG 3.7 and that group could be open to the inclusion of new members by means of direct contact with other academics who have published articles related to the discipline.

Finally, and given the importance of this field in practice, there should be a debate within ITEM about what topics should be the object of future research. The aim would be to link research to market interest, in other words, not to widen the present gap between the direction taken by theoretical research works and that followed by practical application in the educational management activity.

\section{APPENDIX}

Table 3 shows the results of articles found in the ISI Web of Knowledge. The search was performed combining the terms (compute* OR tech* OR IT OR information technology OR IS OR IS/IT OR inf* syst*) AND (education* admin* OR education* management). From the list obtained, a tighter search was carried out by reading the abstracts to select only those papers which better fitted the scope of ITEM.

Table 3: Papers extracted the ISI Web of Knowledge to perform the analysis

\begin{tabular}{|c|c|c|c|}
\hline Title & Author(s) & Source & Date \\
\hline $\begin{array}{l}\text { Cyber schooling framework: } \\
\text { Improving mobility and situated } \\
\text { learning }\end{array}$ & $\begin{array}{l}\text { Chen NS, } \\
\text { Kinshuk, Wang } \\
\text { YH } \\
\end{array}$ & $\begin{array}{l}\text { International journal } \\
\text { of engineering } \\
\text { education }\end{array}$ & 2007 \\
\hline $\begin{array}{l}\text { Development of eMed: A } \\
\text { comprehensive, modular } \\
\text { curriculum-management system }\end{array}$ & $\begin{array}{l}\text { Watson EGS, } \\
\text { Moloney PJ, } \\
\text { Toohey SM } \\
\end{array}$ & Academic medicine & 2007 \\
\hline $\begin{array}{l}\text { Improving the utilisation of } \\
\text { management information systems } \\
\text { in secondary schools }\end{array}$ & $\begin{array}{l}\text { Bosker RJ, } \\
\text { Branderhorst EM, } \\
\text { Visscher AJ }\end{array}$ & $\begin{array}{l}\text { School effectiveness } \\
\text { and school } \\
\text { improvement }\end{array}$ & 2007 \\
\hline $\begin{array}{l}\text { Systems limitations hamper } \\
\text { integration of accessible } \\
\text { information technology in } \\
\text { northwest USK-12 schools }\end{array}$ & $\begin{array}{l}\text { Wisdom JP, White } \\
\text { N, Goldsmith K, } \\
\text { et al. }\end{array}$ & $\begin{array}{l}\text { Educational } \\
\text { technology \& society }\end{array}$ & 2007 \\
\hline $\begin{array}{l}\text { Data for school improvement: } \\
\text { Factors for designing effective } \\
\text { information systems to support } \\
\text { decision-making in schools }\end{array}$ & Breiter A, Light D & $\begin{array}{l}\text { Educational } \\
\text { technology \& society }\end{array}$ & 2006 \\
\hline $\begin{array}{l}\text { Complexity of integrating } \\
\text { computer technologies into } \\
\text { education in Turkey }\end{array}$ & Akbaba-Altun S & $\begin{array}{l}\text { Educational } \\
\text { Technology \& } \\
\text { Society }\end{array}$ & 2006 \\
\hline All aboard-destination unknown: & Goldberg AK, & Educational & 2006 \\
\hline
\end{tabular}




\begin{tabular}{|c|c|c|c|}
\hline $\begin{array}{l}\text { A sociological discussion of } \\
\text { online learning }\end{array}$ & Riemer FJ & technology \& society & \\
\hline $\begin{array}{l}\text { School technology leadership: } \\
\text { An empirical investigation of } \\
\text { prevalence and effect }\end{array}$ & $\begin{array}{l}\text { Anderson RE, } \\
\text { Dexter S }\end{array}$ & $\begin{array}{l}\text { Educational } \\
\text { administration } \\
\text { quarterly }\end{array}$ & 2005 \\
\hline $\begin{array}{l}\text { Using information and } \\
\text { communication technology in } \\
\text { secondary schools in Nigeria: } \\
\text { Problems and prospects }\end{array}$ & $\begin{array}{l}\text { Aduwa-Ogiegbaen } \\
\text { SE, Iyamu EOS }\end{array}$ & $\begin{array}{l}\text { Educational } \\
\text { technology \& society }\end{array}$ & 2005 \\
\hline $\begin{array}{l}\text { An approach to assisting teachers } \\
\text { in building physical and network } \\
\text { hybrid community-based } \\
\text { learning environments: the } \\
\text { Taiwanese experience }\end{array}$ & $\begin{array}{l}\text { Chang LJ, Chou } \\
\text { CY, Chen ZH }\end{array}$ & $\begin{array}{l}\text { International journal } \\
\text { of educational } \\
\text { development }\end{array}$ & 2004 \\
\hline $\begin{array}{l}\text { Education project management in } \\
\text { the information age: the case of } \\
\text { the Kimberley Thusanang Project }\end{array}$ & Harvey S & $\begin{array}{l}\text { International journal } \\
\text { of educational } \\
\text { development }\end{array}$ & 2004 \\
\hline $\begin{array}{l}\text { Examining teachers' decisions to } \\
\text { adopt new technology }\end{array}$ & $\begin{array}{l}\text { Sugar W, Crawley } \\
\text { F, Fine B }\end{array}$ & $\begin{array}{l}\text { Educational } \\
\text { technology \& society }\end{array}$ & 2004 \\
\hline $\begin{array}{l}\text { Meta-knowledge - a success } \\
\text { factor for computer-supported } \\
\text { organizational learning in } \\
\text { companies }\end{array}$ & $\begin{array}{l}\text { Herrmann T, } \\
\text { Kienle A, } \\
\text { Reiband N }\end{array}$ & $\begin{array}{l}\text { Educational } \\
\text { technology \& society }\end{array}$ & 2003 \\
\hline $\begin{array}{l}\text { Evaluation of the } \\
\text { implementation, use and effects } \\
\text { of a computerised management } \\
\text { information system in English } \\
\text { secondary schools }\end{array}$ & $\begin{array}{l}\text { Visscher A, Wild } \\
\text { P, Smith D, et al. }\end{array}$ & $\begin{array}{l}\text { British journal of } \\
\text { educational } \\
\text { technology }\end{array}$ & 2003 \\
\hline $\begin{array}{l}\text { Teacher training on technology- } \\
\text { enhanced instruction - A holistic } \\
\text { approach }\end{array}$ & $\begin{array}{l}\text { Tan SC, Hu C, } \\
\text { Wong SK }\end{array}$ & $\begin{array}{l}\text { Educational } \\
\text { technology \& society }\end{array}$ & 2003 \\
\hline $\begin{array}{l}\text { Public school administrators and } \\
\text { technology policy making }\end{array}$ & Nance JP & $\begin{array}{l}\text { Educational } \\
\text { administration } \\
\text { quarterly }\end{array}$ & 2003 \\
\hline $\begin{array}{l}\text { The professional development of } \\
\text { principals: Innovations and } \\
\text { opportunities }\end{array}$ & Peterson K & $\begin{array}{l}\text { Educational } \\
\text { administration } \\
\text { quarterly }\end{array}$ & 2002 \\
\hline $\begin{array}{l}\text { Information technology in dental } \\
\text { education }\end{array}$ & Yip HK, Barnes IE & British dental journal & 1999 \\
\hline $\begin{array}{l}\text { New technologies and the } \\
\text { cultural ecology of primary } \\
\text { schooling: Imagining teachers as } \\
\text { Luddites in/deed }\end{array}$ & $\begin{array}{l}\text { Bryson } \mathrm{M}, \mathrm{DE} \\
\text { Castell S }\end{array}$ & Educational policy & 1998 \\
\hline $\begin{array}{l}\text { Computer-based simulations of } \\
\text { the school principalship: } \\
\text { Preparation for professional } \\
\text { practice }\end{array}$ & $\begin{array}{l}\text { Maynes B, } \\
\text { McIntosh G, } \\
\text { Mappin D }\end{array}$ & $\begin{array}{l}\text { Educational } \\
\text { administration } \\
\text { quarterly }\end{array}$ & 1996 \\
\hline $\begin{array}{l}\text { MIS implementation in schools: } \\
\text { A systems socio-technical } \\
\text { framework }\end{array}$ & Telem M & $\begin{array}{l}\text { Computers \& } \\
\text { education }\end{array}$ & 1996 \\
\hline $\begin{array}{l}\text { Selecting a commercial clinical } \\
\text { information-system - an }\end{array}$ & $\begin{array}{l}\text { Wont ET, } \\
\text { Abendroth TW }\end{array}$ & $\begin{array}{l}\text { Journal of the } \\
\text { American medical }\end{array}$ & 1994 \\
\hline
\end{tabular}




\begin{tabular}{|c|c|c|c|}
\hline \multicolumn{2}{|l|}{$\begin{array}{l}\text { academic medical-centers } \\
\text { experience }\end{array}$} & \multicolumn{2}{|l|}{$\begin{array}{l}\text { informatics } \\
\text { association }\end{array}$} \\
\hline $\begin{array}{l}\text { Staff usage of information } \\
\text { technology in a faculty of higher- } \\
\text { education - a survey and case- } \\
\text { study }\end{array}$ & Schwieso J & $\begin{array}{l}\text { Educational \& } \\
\text { training technology } \\
\text { international }\end{array}$ & 1993 \\
\hline Distance learning partnership & Brownridge IC & Education & 1993 \\
\hline $\begin{array}{l}\text { Campus computing - a big } \\
\text { approach by a small college }\end{array}$ & $\begin{array}{l}\text { NEAL CV, } \\
\text { KELSEY DH }\end{array}$ & Education & 1993 \\
\hline $\begin{array}{l}\text { Brain train - professional- } \\
\text { education and training } \\
\text { requirements in developing- } \\
\text { countries }\end{array}$ & Keenan S & $\begin{array}{l}\text { Education for } \\
\text { information }\end{array}$ & 1992 \\
\hline The role of the British-council & Bate $\mathrm{G}$ & $\begin{array}{l}\text { Education for } \\
\text { information }\end{array}$ & 1992 \\
\hline $\begin{array}{l}\text { EMS - case-study in } \\
\text { methodology for designing } \\
\text { knowledge-based systems and } \\
\text { information-systems }\end{array}$ & $\begin{array}{l}\text { Zhang Y, } \\
\text { Hitchcock P }\end{array}$ & $\begin{array}{l}\text { Information and } \\
\text { software technology }\end{array}$ & 1991 \\
\hline $\begin{array}{l}\text { Effectiveness of computer- } \\
\text { assisted special-education } \\
\text { administration simulations }\end{array}$ & $\begin{array}{l}\text { Schloss PJ, } \\
\text { Cartwright GP, } \\
\text { Smith MA }\end{array}$ & $\begin{array}{l}\text { Journal of special } \\
\text { education }\end{array}$ & 1986 \\
\hline $\begin{array}{l}\text { Voluntary technological growth - } \\
\text { an administrative challenge }\end{array}$ & Rhodes LA & $\begin{array}{l}\text { Educational } \\
\text { leadership }\end{array}$ & 1984 \\
\hline $\begin{array}{l}\text { A national status-report on the } \\
\text { use of electronic technology in } \\
\text { special-education management }\end{array}$ & $\begin{array}{l}\text { Burrello LC, } \\
\text { Tracy Ml, } \\
\text { Glassman EJ }\end{array}$ & $\begin{array}{l}\text { Journal of special } \\
\text { education }\end{array}$ & 1983 \\
\hline $\begin{array}{l}\text { Harnessing the computer in } \\
\text { educational management }\end{array}$ & Clemson B & $\begin{array}{l}\text { Journal of } \\
\text { educational } \\
\text { administration }\end{array}$ & 1980 \\
\hline $\begin{array}{l}\text { Information-systems and } \\
\text { educational-administration - } \\
\text { totally inseparable and generally } \\
\text { archaic }\end{array}$ & Simmons JR & $\begin{array}{l}\text { Educational } \\
\text { technology }\end{array}$ & 1979 \\
\hline $\begin{array}{l}\text { Application of computer to an } \\
\text { educational management } \\
\text { problem - from naivety to } \\
\text { frustration, to victory }\end{array}$ & Schmitt NJ & $\begin{array}{l}\text { Educational } \\
\text { technology }\end{array}$ & 1976 \\
\hline $\begin{array}{l}\text { Considerations in design of } \\
\text { information-systems for } \\
\text { educational management }\end{array}$ & Bruno JE & Management & 1975 \\
\hline $\begin{array}{l}\text { Educational management } \\
\text { information systems for seventies }\end{array}$ & Hayman JL & $\begin{array}{l}\text { Educational } \\
\text { administration } \\
\text { quarterly }\end{array}$ & 1974 \\
\hline $\begin{array}{l}\text { Systems technology and operant } \\
\text { conditioning in organization and } \\
\text { administration of university } \\
\text { affiliated facility for mental } \\
\text { retardation }\end{array}$ & Throne JM & $\begin{array}{l}\text { Educational } \\
\text { technology }\end{array}$ & 1973 \\
\hline $\begin{array}{l}\text { Training educational managers } \\
\text { via educational technology }\end{array}$ & $\begin{array}{l}\text { Banghart FW, } \\
\text { Harris E, Mcgee J }\end{array}$ & $\begin{array}{l}\text { Educational } \\
\text { technology }\end{array}$ & 1973 \\
\hline Technology-based educational & Hayman RW, & Educational & 1972 \\
\hline
\end{tabular}




\begin{tabular}{|c|c|c|c|}
\hline $\begin{array}{l}\text { system using computer } \\
\text { management }\end{array}$ & Lord W & technology & \\
\hline $\begin{array}{l}\text { Use of computer in educational } \\
\text { management }\end{array}$ & Shaw DC & $\begin{array}{l}\text { Educational } \\
\text { technology }\end{array}$ & 1972 \\
\hline $\begin{array}{l}\text { Information system design for } \\
\text { educational management }\end{array}$ & $\begin{array}{l}\text { Turksen IB, } \\
\text { Holzman AG }\end{array}$ & $\begin{array}{l}\text { Socio-economic } \\
\text { planning sciences }\end{array}$ & 1972 \\
\hline $\begin{array}{l}\text { Trends in administrative } \\
\text { technology }\end{array}$ & Engel RA & Education & 1971 \\
\hline $\begin{array}{l}\text { Computer-aided education } \\
\text { management - integrated records } \\
\text { and counseling system }\end{array}$ & $\begin{array}{l}\text { Thrasher CL, } \\
\text { Campbell JH, } \\
\text { Bennett GE }\end{array}$ & $\begin{array}{l}\text { Journal of } \\
\text { educational data } \\
\text { processing }\end{array}$ & 1971 \\
\hline $\begin{array}{l}\text { Instructional technology and } \\
\text { administrative decisions }\end{array}$ & $\begin{array}{l}\text { Eye GG, Garrison } \\
\text { Mb, Kuhn JA }\end{array}$ & $\begin{array}{l}\text { Educational } \\
\text { technology }\end{array}$ & 1969 \\
\hline $\begin{array}{l}\text { Technology of computers and } \\
\text { systems analysis - impact on } \\
\text { school management }\end{array}$ & Mcloone EP & $\begin{array}{l}\text { Educational } \\
\text { technology }\end{array}$ & 1969 \\
\hline $\begin{array}{l}\text { Educational technology - } \\
\text { economics, management and } \\
\text { public policy }\end{array}$ & $\begin{array}{l}\text { Randall R, } \\
\text { Blaschke C }\end{array}$ & $\begin{array}{l}\text { Educational } \\
\text { technology }\end{array}$ & 1968 \\
\hline $\begin{array}{l}\text { Computer concepts and } \\
\text { educational administration }\end{array}$ & $\begin{array}{l}\text { Caffrey J } \\
\text { Marker,RW, } \\
\text { McGraw,PP and } \\
\text { Stone,FD }\end{array}$ & Educational record & 1967 \\
\hline
\end{tabular}

\section{REFERENCES}

Clancy, D.K. (1978). "The management control problems of responsibility accounting". Management Accounting, March.

Corr, A.V. (1977). "Accounting information for managerial decision". Financial Executive. August.

Fleming, M.L. and Levie, W.H. (1978). Instructional message design. Principles from the behavioural sciences. Educational Technology Publications. Englewood Cliffs, NJ.

Gorry, A. and Scott Morton, M. (1971). "A framework for management information systems". Sloan Management Review. Vol. 13, No 1.

Heinich, R. (1970). Technology and the management of instruction. Association for Educational Communication and Technology. Washington, DC.

Linn, M.; Bell, P. and Hsi, S (1998). "Using the Internet to enhance student understanding of science: The knowledge integration environment". Interactive Learning Environments. Vol. 6, pp 4-38.

Lubas, D.P. (1976). "Developing a computerized general ledger system". Management Accounting. May, pp-53-65.

McKinsey \& Company (1968). Unlocking the computer profit potential. McKinsey, Mass. 
Miesing, P. (1998). B-Schools on the I-way. Journal of Management Education. Vol. 22, No. 3, pp 753-770.

Osorio, J. and Bulchand, J. (2007). "Ten years of ITEM research: Analysis of WG 3.7's Publisher work (1994-2004)", in Tatnall, A., Okamoto, T. and Visscher, A. (eds.) Knowledge Management for Educational Innovation. Springer. New York.

Spencer, K. (1991). "Modes, media and methods: the search for educational effectiveness". British Journal of Educational Technology. Vol. 30, No. 1, pp. 12-22.

Wagner, G.R. (1970). "Decision Support Systems: computerized mind support for executive problems" Managerial Planning. Sept-Oct.

William, W. (2002). "Current trends in educational technology research: the study of learning environments. 